\title{
Contribution to the knowledge of the freshwater Ostracoda fauna in continental Portugal, with an updated checklist of Recent and Quaternary species
}

\author{
Maria João FERNANDES MARTINS ${ }^{1,2,3) *}$, Tadeusz NAMIOTKO ${ }^{1)}$, Maria Cristina CABRAL ${ }^{2)}$, \\ Francisco FATELA ${ }^{2)}$ and Maria José BOAVIDA ${ }^{3)}$ \\ ${ }^{1)}$ University of Gdańsk, Department of Genetics, Laboratory of Limnozoology, Kładki 24, 80-822 Gdańsk, Poland \\ ${ }^{2)}$ University of Lisbon, Faculty of Sciences, Center of Geology, Campo Grande, C6, 4 Piso, 1749-016 Lisboa, Portugal \\ ${ }^{3)}$ University of Lisbon, Faculty of Sciences, Center of Environmental Biology, Campo Grande, C2, 1749-016 Lisboa, Portugal \\ *e-mail corresponding author: mariajoao.martins@eawag.ch
}

\begin{abstract}
Ostracods have a ubiquitous distribution, a high diversity of life history strategies and an extensive fossil record. These characteristics make the group a useful study tool in multiple disciplines. In Portugal, very few studies on recent freshwater ostracods have been published. This is particularly important given the need for an accurate database of both autoecology and geographical distribution of the extant species for a correct use of these crustaceans as environmental proxies. Six temporary ponds were periodically sampled during the wet season 2005/2006, in the natural park "Parque Natural do Sudoeste Alentejano e Costa Vicentina" (PNSACV) north of Vila Nova de Milfontes, SW Portugal. The relationship between ostracod assemblages and habitat features was analysed. In parallel, to assess relative ostracod species richness and diversity, faunistic results are also presented based on a regional (Alentejo) survey carried out during the same season. The semi-permanent nature of the study area in PNSACV may contribute to the observed relative high ostracod richness. Yet other environmental factors, such as $p H$ and pond hydroperiod variation, may restrict the local ostracod species distribution and its abundance. The most abundant and/or common ostracod species were eurytopic forms: Cypridopsis vidua, Cypris bispinosa and Herpetocypris chevreuxi. A total of 14 species was identified, of which three named and one most probably undescribed candonid species new to Portugal: Bradleycypris obliqua, C. bispinosa, Paralimnocythere psammophila and Fabaeformiscandona $s p$. ex gr. fabaeformis. In the regional survey nine species were identified. Heterocypris sp., Ilyocypris aff. lacustris and Tonnacypris lutaria were recorded in the regional survey but not present in PNSACV, with the latter two also new in Portugal. To favour further faunistic and ecological research on ostracods in Portugal, a distributional checklist of Recent and Quaternary freshwater inland Ostracoda known from Portuguese mainland is given.
\end{abstract}

Key words: autoecology, distribution check-list, hydroperiod variation, temporary ponds

\section{INTRODUCTION}

The Ostracoda are small bivalved crustaceans abundant in nearly all non-marine and marine habitats, but also found in semi-terrestrial environments (Cohen \& Morin 1990; Holmes \& Chivas 2002). The taxon exhibits a high taxonomical diversity and an extensive fossil record, product of an easily fossilizable calcitic bivalve carapace (Moore 1961). Moreover, an impressive diversity of life history strategies and reproductive modes has been reported, in particular within the non-marine ostracods (Chaplin et al. 1994; Butlin et al. 1998). Their narrow environmental preferences (e.g., Carbonel et al. 1988) define them as potential bioindicators for monitoring of recent freshwater conditions (e.g., Roca et al. 2000; Külköylüoğlu 2004) and excellent proxies of past environmental changes (Carbonel et al. 1988). Given these unique characteristics, the group provides an excellent study tool in multidisciplinary disciplines as (palaeo)ecology or evolutionary biology.

Although the study of ostracods was initiated in the 18th century (Oertli 1982), regionally only the Holarctic fauna of freshwater ostracods is considered reasonably well documented (Meisch 2000; Martens et al. 2008).
Still, Portugal is an exception. The present study aims at extending the knowledge on Portuguese freshwater ostracod fauna.

The earliest known evidence of freshwater ostracods in mainland Portugal is that of Petkovski $(1963 ; 1964)$ with reference to two species from mainland Portugal, unfortunately not providing any geographical details. Subsequently, Paulo (1969) recorded three freshwater species from the Douro region, North Portugal, one of which (Herpetocypris mateusorum) new to science. Much of the knowledge on the recent freshwater ostracod fauna in mainland Portugal results from the work carried out by Paulo \& Moutinho (1983). These records are based on surveys carried out within Portugal (continent and islands), and extending from fresh and brackish waters to marine habitats. The article gives a list of 23 freshwater species with geographical and some ecological details. More recently González-Mozo et al. (1996) in a taxonomic revision of the genus Herpetocypris provided new records for four species of this genus in two regions of Portugal. In the same year, Baltanás et al. (1996) released a faunistic list of recent freshwater ostracods occurring in the Iberian Peninsula, including continental Portugal. Yet, all records but one 
within the list result from the previously published data, little extending our knowledge of the Portuguese fauna. The latest published papers including new records of Recent fresh- and brackish-water ostracod species for Portugal were that of Cearreta et al. (2003), Cabral et al. (2006), Hilbich et al. (2008) and Loureiro et al. (2009).

Horne (2004) in the Fauna Europaea database recapitulated all records from continental Portugal and provided a species list of 27 inland freshwater ostracod species although the record of Dolerocypris sinensis (Sars 1903) is most probably erroneous (C. Meisch, pers. comm.). The five species of the families Leptocytheridae and Loxoconchidae plus Cyprideis torosa (Jones 1859), classified as brackish and/or marine forms, were not considered in the present work. More information on these species may be found in recent studies on fossil and recent material in mainland Portugal (e.g., Hindson \& Andrade 1999; Hindson et al. 1999; Cabral et al. 2006; Loureiro et al. 2009). The record of 26 species for mainland Portugal is modest if compared to that of mainland Spain with 80 recent inland freshwater species (Horne 2004), or with those of other European countries of similar geographical area as Austria (81 species) or Hungary (86 species) (Meisch 2000). Continual work in mainland Portugal is, therefore, required for a real picture of the freshwater ostracod fauna, especially in view of the work known from Spain. Such a study seems even more justified by the fact that, among the species known to occur in continental Portugal, four have not (yet) been recorded in Spain.

Continental Portugal, given its geographical position and geophysical features, is characterised by dry summers and moderate rainy winters with natural large permanent water bodies virtually absent (Ribeiro \& Lautensach 1988). Therefore, temporary pools play an essential role as repositories of a diverse and valuable genetic heritage, with Temporary Mediterranean Ponds classified as a priority habitat by the European Directive 92/43/EEC (Habitats Directive, Annex I, Council Directive 92/43/EEC). The freshwater ostracods are one of the most characteristic and abundant group of meiobenthic invertebrates in lentic shallow waters (Giere 2009). In this work we present data collected in six temporary ponds monitored over one hydroperiod in the natural park "Parque Natural do Sudoeste Alentejano e Costa Vicentina" (PNSACV), Baixo Alentejo, Portugal. The sampling area was chosen because of its relatively limited human occupation, easy field accessibility and presence of large depressed zones favourable to keep frequent shallow water bodies.

Possible relationships between habitat features and ostracod assemblage dynamics were analysed. To assess the relative ostracod species richness of the study area, located in a protected area, a parallel survey was carried out in temporary ponds in the Alentejo region (Alto and Baixo Alentejo). The pooled results and species list produced were compared to previously published data for continental Portugal.

\section{MATERIAL AND METHODS}

\subsection{Regional settings}

\subsubsection{Natural park PNSACV}

The PNSACV is located on the SW coastline of Portugal. The park is $110 \mathrm{~km}$ long with an area of approximately 57,000 ha, where several natural habitats may be found (e.g., cliffs, beaches, small islands, fossil reefs, small canyons, the River Mira estuary, dunes, salt marshes, temporary ponds). The detailed geology of the zone may be checked in the Carta Geológica de Portugal (1:200,000), Folha 7, Serviços Geológicos de Portugal (Oliveira 1984). It is essentially represented by sands, sandstones and gravels from the Plio-Pleistocene and less frequently from the Holocene and Recent; to the interior and in the south, the area contains a wide variety of Palaeozoic rocks. In the northern part of the park (near V. N. Milfontes), in depression areas of the dunes of Holocene age, some surface water bodies can be found during the rainy season. A larger one ( $\mathrm{ca} 500 \times$ $120 \mathrm{~m}$ ), stands out for its size and semi-permanent nature, almost permanent, which is probably caused by the existence of accumulated mud at the bottom preventing infiltration of the rain waters. The catchment area is broadly delimited in figure 1 . The region is under a Mediterranean climate, with an average annual precipitation between $570 \mathrm{~mm}$ in inland and $720 \mathrm{~mm}$ close to the coast, where Atlantic influence is recorded (www.meteo.pt).

\subsubsection{Regional survey}

The Alentejo region (Alto and Baixo Alentejo) (Fig. 2) has a diverse geology (Carta Geológica de Portugal, 1:500,000, Serviços Geológicos de Portugal, Oliveira et al. 1992), mostly represented by Palaeozoic metamorphic and igneous rocks. Regarding the ponds sampled in the Alentejo region, local geology has little importance, since all are of temporary nature, located along roads, in small roadside depressions. The climate of the region is also Mediterranean, but with precipitation decreasing towards the inner area.

\subsection{Sampling}

\subsubsection{Natural park PNSACV}

The area of the study sites is approximately $1 \mathrm{~km}^{2}$ and it is located at altitudes of ca 50-58 m a.s.l. (Tab. 1). Since the sampled area is located inside a natural park, it is under reduced human activity, serving as pasture grounds. Sampling was carried out on three occasions (22 December 2005, 5 January 2006 and 27 April 2006), surveying a total of six temporary ponds (Fig. 1). Despite being part of a single basin area, all ponds were isolated at the sampling times except ponds Font 2, 3 and 4 which were connected in April (coded for this date as Font 2-4). 


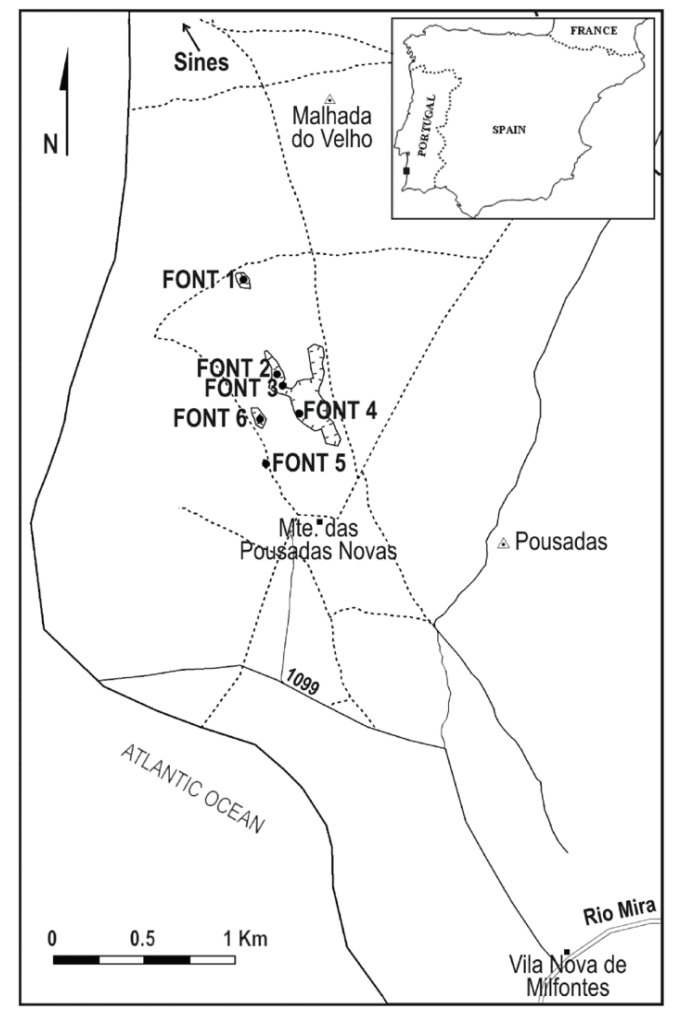

Fig. 1. Location map of the study sites with indication of the six ponds sampled in the natural park PNSACV.

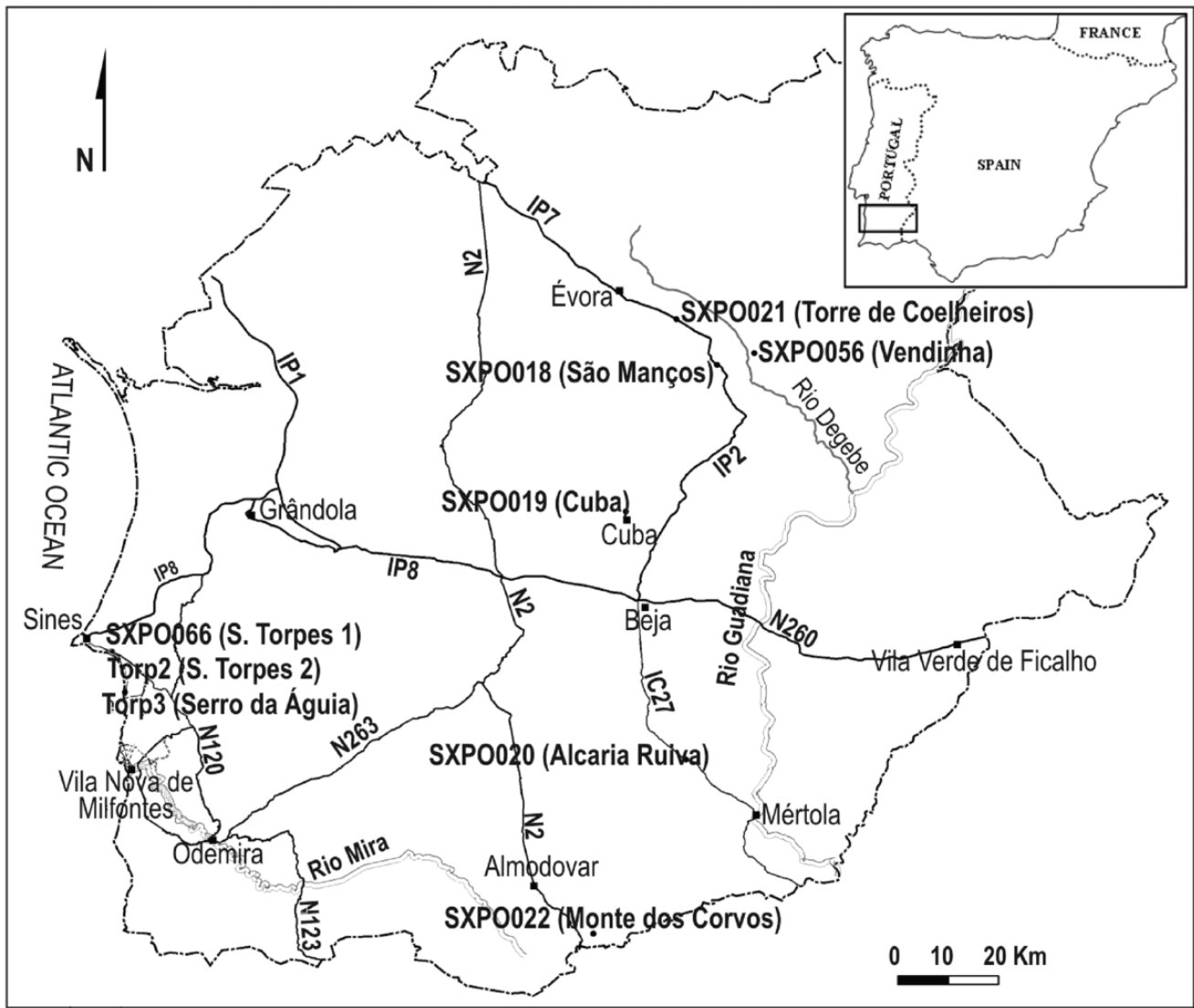

Fig. 2. Location map of the nine ponds sampled in the Alentejo regional survey. 
Tab. 1. Pond names, codes, values for the environmental variables in chronological order (December-JanuaryApril), coordinates and altitudes for the six ponds sampled in the natural park PNSACV.

\begin{tabular}{|c|c|c|c|c|c|c|c|}
\hline $\begin{array}{l}\text { Pond } \\
\text { Code }\end{array}$ & & $\begin{array}{c}\text { Font } 1 \\
1\end{array}$ & $\begin{array}{c}\text { Font } 2 \\
2\end{array}$ & $\begin{array}{c}\text { Font } 3 \\
3\end{array}$ & $\begin{array}{c}\text { Font } 4 \\
4\end{array}$ & $\begin{array}{c}\text { Font } 5 \\
5\end{array}$ & $\begin{array}{c}\text { Font } 6 \\
6\end{array}$ \\
\hline Water temperature $\left({ }^{\circ} \mathrm{C}\right)$ & Temp & $14.5-26.3$ & 13.9-13.5-18.9 & 16.4-18.9 & $10.0-9.2-18.9$ & $9.6-22.7$ & 20.8 \\
\hline Salinity (\%o) & Sal & $0.6-0.1$ & $0.3-0.3-0.2$ & $0.5-0.2$ & $1.3-0.9-0.2$ & $0.7-0.1$ & 0.4 \\
\hline $\mathrm{pH}$ & $\mathrm{pH}$ & $6.0-7.0$ & $6.3-6.3-6.5$ & $6.5-6.5$ & $5.0-5.0-6.5$ & $5.0-6.3$ & 6.4 \\
\hline Conductivity $\left(\mu \mathrm{S} \mathrm{cm}^{-1}\right)$ & Cond & $1589-689$ & $1095-1071-885$ & $1445-885$ & $2799-1955-885$ & $1198-777$ & 1213 \\
\hline Dissolved Oxygen (\%) & $\mathrm{O}_{2}$ & $95.1-2.0$ & $66.8-28.1-20.1$ & $44.4-20.1$ & $11.0-14.7-20.1$ & $69.0-2.2$ & 9.4 \\
\hline Latutude & & $\mathrm{N} 37^{\circ} 45^{\prime} 26^{\prime \prime}$ & $\mathrm{N} 37^{\circ} 45^{\prime} 09^{\prime \prime}$ & $\mathrm{N} 37^{\circ} 45^{\prime} 07^{\prime \prime}$ & $\mathrm{N} 37^{\circ} 45^{\prime} 02^{\prime \prime}$ & N37 $47^{\circ}{ }^{\prime} 53^{\prime \prime}$ & $\mathrm{N} 37^{\circ} 45^{\prime} 01^{\prime \prime}$ \\
\hline Longitude & & W8 $47^{\circ} 52^{\prime \prime}$ & W8 $47^{\prime} 46^{\prime \prime}$ & W8 $47^{\prime} 45^{\prime \prime}$ & W8 $47^{\prime} 42^{\prime \prime}$ & $\mathrm{W} 8^{\circ} 47^{\prime} 48^{\prime \prime}$ & W8 $47^{\prime} 49^{\prime \prime}$ \\
\hline Altitude (m a.s.l.) & & 58 & 56 & 56 & 55 & 50 & 55 \\
\hline
\end{tabular}

Tab. 2. Pond names, field codes, closest localities, coordinates and altitudes for the nine ponds sampled in the Alentejo regional survey, plus information on ostracod species recorded in each pond. ${ }^{2}$ - includes records of males in species reproducing primarily by parthenogenesis.

\begin{tabular}{|c|c|c|c|c|c|c|c|c|c|}
\hline Pond name & São Manços & Cuba & $\begin{array}{l}\text { Alcaria } \\
\text { Ruiva }\end{array}$ & $\mathrm{N} 182^{\text {nd }}$ & $\begin{array}{l}\text { Monte dos } \\
\text { Corvos }\end{array}$ & $\mathrm{N} 2562^{\text {nd }}$ & S. Torpes 1 & S. Torpes 2 & $\begin{array}{l}\text { Serro da } \\
\text { Águia }\end{array}$ \\
\hline Code & SXPO018 & SXPO019 & SXPO020 & SXPO021 & SXPO022 & SXPO056 & SXPO066 & Torp2 & Torp3 \\
\hline Closest locality & São Mancos & Cuba & $\begin{array}{c}\text { Alcaria } \\
\text { Ruiva }\end{array}$ & $\begin{array}{l}\text { Torre de } \\
\text { Coelheiros }\end{array}$ & $\begin{array}{l}\text { Monte dos } \\
\text { Corvos }\end{array}$ & Vendinha & Sines & Sines & Sines \\
\hline Latitude & N38 $26^{\circ} 37^{\prime \prime}$ & $\mathrm{N} 38^{\circ} 10^{\prime} 58^{\prime \prime}$ & N37 $34^{\circ} 4^{\prime} 29^{\prime \prime}$ & N38 $38^{\circ} 1^{\prime 3} 1^{\prime \prime}$ & N37 $25^{\circ} 56^{\prime \prime}$ & N38 $28^{\circ} 34^{\prime \prime}$ & N37 $37^{\circ} 05^{\prime \prime}$ & N37ㅇ5 $56^{\prime} 00^{\prime \prime}$ & N3751'42" \\
\hline Longitude & W7º44'01" & $\mathrm{W}^{\circ} 53^{\prime} 50^{\prime \prime}$ & W7'47'20" & W7 $7^{\circ} 48^{\prime} 23^{\prime \prime}$ & W7057'19" & W7 $7^{\circ} 40^{\prime} 02^{\prime \prime}$ & W8 $49^{\circ} 07^{\prime \prime}$ & W8 $48^{\prime} 58^{\prime \prime}$ & W8 $47^{\circ} 36^{\prime \prime}$ \\
\hline Altitude m a.s.l. & 187 & 186 & 163 & 235 & 336 & 199 & 10 & 7 & 17 \\
\hline $\begin{array}{l}\text { Candona sp. ex gr. neglecta } \\
\text { Cypridopsis hartwigi } \\
\text { Cypridopsis vidua }\end{array}$ & & & $\mathrm{X}$ & $\mathrm{X}$ & $\mathrm{X}$ & & & & \\
\hline Eucypris virens & X & $\mathrm{X}$ & $\mathrm{X}^{\hat{2}}$ & $\mathrm{X}$ & $\mathrm{X}^{2}$ & $X$ & $X$ & $\mathrm{X}$ & X \\
\hline $\begin{array}{l}\text { Heterocypris incongruens } \\
\text { Heterocypris } \mathrm{sp} .\end{array}$ & $\mathrm{X}$ & $\mathrm{X}$ & $X$ & $\mathrm{X}$ & $\mathrm{X}$ & $\mathrm{X}$ & $\mathrm{X}$ & $\mathrm{X}$ & $\mathrm{X}$ \\
\hline Ilyocypris gibba & & & & & & & & $\mathrm{X}$ & $\mathrm{X}$ \\
\hline Ilyocypris aff. lacustris & & $\mathrm{X}$ & & $X$ & & & $\mathrm{X}$ & & \\
\hline $\begin{array}{l}\text { Paralimnocythere psammophila } \\
\text { Tonnacypris lutaria }\end{array}$ & $X$ & & $\mathrm{X}$ & $X$ & & & & & \\
\hline
\end{tabular}

Ponds were shallow (depth $<1.5 \mathrm{~m}$ ) and rainwater fed. Water presence in the area was first confirmed in December 2005. Pond hydroperiod was variable throughout the sampling period conditioning sampling regularity: Ponds Font 2 and Font 4 were filled in December 2005; the remaining ponds were filled in January except for pond Font 6, still empty at this date. The last pond was sampled in the last sampling date only (27 April 2006). The bottom of the ponds was (partially) covered by grassy vegetation dominated mostly by the common reed Phragmites sp. (not observed in site Font 1 in January).

Ostracods were sampled semi-quantitatively by sweeping the bottom (superficial sediment and adjacent water column) of the pond using a rectangular hand net $(25 \times 15 \mathrm{~cm}$; mesh size: $0.12 \mathrm{~mm})$ at two to six sampling points, depending on pond area. The samples were pooled and immediately preserved in 30\% ethanol. Ostracod abundances were standardized for all ponds and expressed as number of individuals per sampling unit (ca $1 \mathrm{~m}^{2}$ of sampled surface area; coded as ind. s.u. ${ }^{-1}$ ). At each sampling occasion, water temperature, salinity, $\mathrm{pH}$, conductivity and dissolved oxygen were measured in situ using electronic probes.

\subsubsection{Regional survey}

The regional survey was carried out from December 2005 until April 2006. Samples were taken during single visits in nine ponds (site names, locations and coordinates are given in table 2). Ponds sampled were located within the region Alentejo (Alto and Baixo Alentejo) but outside the protected area of the natural park PNSACV, in distinctly human impacted areas (Fig. 2). All ponds were temporary, small and shallow water bodies (max. size $50 \times 25 \mathrm{~m}$; depth $<1.5 \mathrm{~m}$ ). Ostracods were collected with a rectangular hand net $(25 \times 15 \mathrm{~cm}$; mesh size: $0.12 \mathrm{~mm}$ ) and immediately fixed in $30 \%$ ethanol.

\subsection{Laboratory work}

Samples were washed under tap water through a $0.25 \mathrm{~mm}$ mesh and preserved in $70 \%$ ethanol. Ostracods were sorted using a stereomicroscope (40× magnification), counted and identified to the species level (when possible) under a stereomicroscope $(100 \times$ magnification) or light transmitted microscope (up to $400 \times$ magnification) using the keys of Meisch (2000). When ostra- 
Tab. 3. Categorized densities of ostracod taxa recorded in the six ponds of the natural park PNSACV per sampling occasion (Dec - 22.12.2005, Jan - 5.1.2006, Apr - 27.4.2006). Ponds are listed and coded in table 1; Scale: $1: 1$ ind. s.u. ${ }^{-1}, 2: 2-10$ ind. s.u. ${ }^{-1}, 3: 11-100$ ind. s.u. ${ }^{-1}, 4: 101-1000$ ind. s.u. ${ }^{-1}, 5:>1000$ ind. s.u..$^{-1}$.

\begin{tabular}{|c|c|c|c|c|c|c|c|c|c|c|c|}
\hline \multirow[b]{2}{*}{ Ponds } & \multicolumn{2}{|c|}{ Dec } & \multicolumn{5}{|c|}{ Jan } & \multicolumn{4}{|c|}{ Apr } \\
\hline & 2 & 4 & 1 & 2 & 3 & 4 & 5 & 1 & $2-4$ & 5 & 6 \\
\hline Bradleycypris obliqua (Brady, 1868) & & & & & & & & 5 & 4 & & 5 \\
\hline Candona sp. ex gr. neglecta & & 3 & & & & & & & & & \\
\hline Cypria ophtalmica (Jurine, 1820) & & 4 & & & 3 & 4 & 3 & & 4 & & \\
\hline Cyprididae indet. juv. & 4 & 3 & 3 & 4 & 4 & 1 & 5 & 3 & 5 & 4 & 5 \\
\hline Cypridopsis hartwigi (G.W. Müller,1900) & & & & & & & & & 1 & 2 & 3 \\
\hline Cypridopsis vidua (O.F. Müller, 1776) & & & & 4 & & & & 3 & 5 & 5 & 5 \\
\hline Cypris bispinosa Lucas, 1849 & 5 & & & 4 & 2 & 1 & 4 & 4 & 4 & 5 & 4 \\
\hline Eucypris virens (Jurine, 1820) & 3 & & & 3 & & & & 3 & & & \\
\hline Fabaeformiscandona sp. n. ex gr. fabaeformis & & 3 & & & & & & & 2 & & \\
\hline Herpetocypris chevreuxi (Sars, 1896) & 4 & & & 4 & 3 & & & 2 & 4 & 5 & 4 \\
\hline Heterocypris incongruens (Ramdohr, 1808) & & & & & & & & 2 & & & \\
\hline Ilyocypris gibba (Ramdohr, 1808) & & & & & & & & 3 & & & \\
\hline Paralimnocythere psammophila (Flössner, 1965) & 3 & & & 4 & 4 & & & 3 & 4 & 3 & 3 \\
\hline Pseudocandona marchica (Hartwig, 1899) & & & & & & & & 3 & & & \\
\hline Sarscypridopsis aculeata (Costa, 1847) & & & & 2 & 2 & & & & 2 & & \\
\hline Ostracoda indet. juv. & & 2 & & 3 & & & & 3 & 2 & 3 & 3 \\
\hline
\end{tabular}

cod densities in a given sample exceeded 1000 ind. s.u. ${ }^{-1}$, the identifications were limited to the animals found in a randomly selected fraction of the total sample (usually 1/2). Ostracod valves were illustrated using Scanning Electron Microscopy (JEOL-JSM5200LV).

\subsection{Statistical analysis}

Principal component analysis (PCA) was applied to summarise the most important environmental gradients in our sites in order to compare these with observed ostracod assemblage structures. Detrended correspondence analysis (DCA) was applied to assess the range of the data set used and linear ordination models were chosen (length of gradient $\mathrm{SD}<2$ ); variables were centred and divided by standard deviation (Lepš \& Šmilauer 2003). From the five variables (Tab. 1), water temperature was removed in the final PCA eliminating strong correlations (highly correlated with salinity and $\mathrm{pH}$; Spearman's correlation $=-0.80$ and 0.83 , respectively, $p$ $<0.05$ ). Conductivity values were $\log$ transformed prior to ordination. Relationships among ostracod site assemblages were examined using a non-metric Multi-Dimensional Scaling (MDS) method based on species relative abundances (categorized densities as explained in Tab. 3) and Bray-Curtis similarity coefficient. Ordination analyses were performed with Canocowin 4.5 (Ter Braak \& Šmilauer 2002); normality assumptions and Spearman's correlation tests were analysed with the statistical program Rwin 2.8.1 (R Development Core Team 2008); MDS procedure was run on PRIMER ver. 6.1.10 software (Clarke \& Gorley 2006).

\section{RESULTS}

\subsection{Natural park PNSACV}

The ranges of the physical and chemical water parameters are reported in table 1. Water conductivity and salinity variation were minimal/absent between Decem- ber and January in Font 2. In Font 4 the variation of these parameters was more evident. An overall decrease in water conductivity and salinity was observed in the five ponds sampled between January and April, whilst the temperature increased in this time period (Tab. 1). In the weeks prior to the April sampling, high precipitation was recorded, which might have contributed to the temporal variation of the recorded variables. Seasonal decrease of dissolved oxygen was intense, in particular in ponds Font 1, 2 and 5, most probably caused by the variation in primary productivity over the season (Tab. 1). However, in Font 4 this pattern was not observed. Slightly acidic $\mathrm{pH}$ values prevailed in all ponds in the study area (pH range: 5.0-7.0). Macrophyte coverage increased between samplings, influencing primary production and affecting seasonal $\mathrm{pH}$ variation, as well as dissolved oxygen percentage of saturation.

A total of 14 ostracod species (Tab. 3) were identified of which two were assigned to the species group only, namely Candona sp. ex gr. neglecta and Fabaeformiscandona sp. ex gr. fabaeformis, the latter probably representing a new species (see comments in 4.1.). Of these, three species were a new record in mainland Portugal: Bradleycypris obliqua, Cypris bispinosa and Paralimnocythere psammophila. Species are illustrated in Appendix Plates A1-A3. The collected material includes also very young juvenile specimens which could not be identified to the species level and were assigned to the family level (Cyprididae). Damaged and/or incomplete specimens were left as indeterminate (Tab. 3).

On average 4.6 species were found per sample, with overall ostracod species richness increasing over the season. The sites with the highest ostracod richness were Font 1 and Font 2-4 in April with nine species identified (Tab. 3). In Font 1, only cypridid juveniles were present in January. An overall increase in ostracod density over the season was also observed, even under 


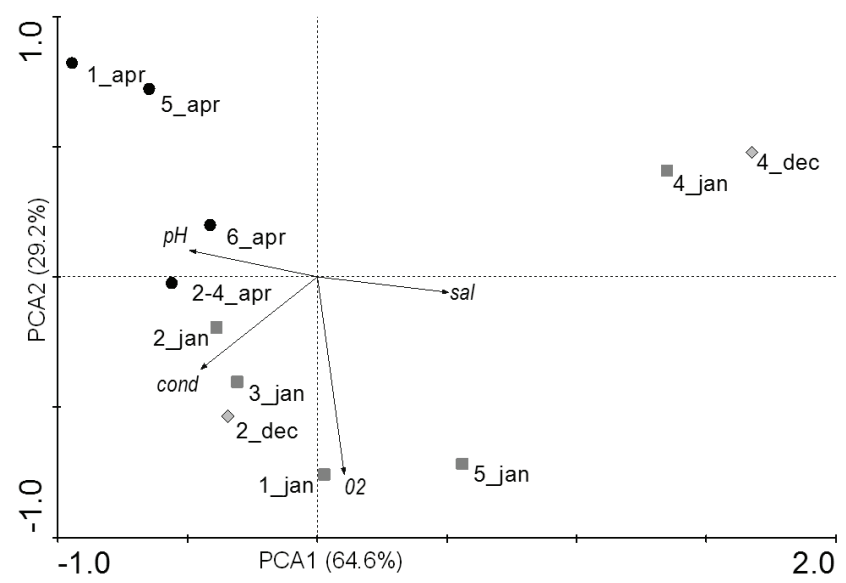

Fig. 3. PCA ordination diagram based on four environmental variables measured at 11 occasions in the six study sites in the natural park PNSACV. Environmental variables and ponds are listed and coded in table 1. Sampling visit is indicated after the pond code (dec - December; jan - January; apr - April).

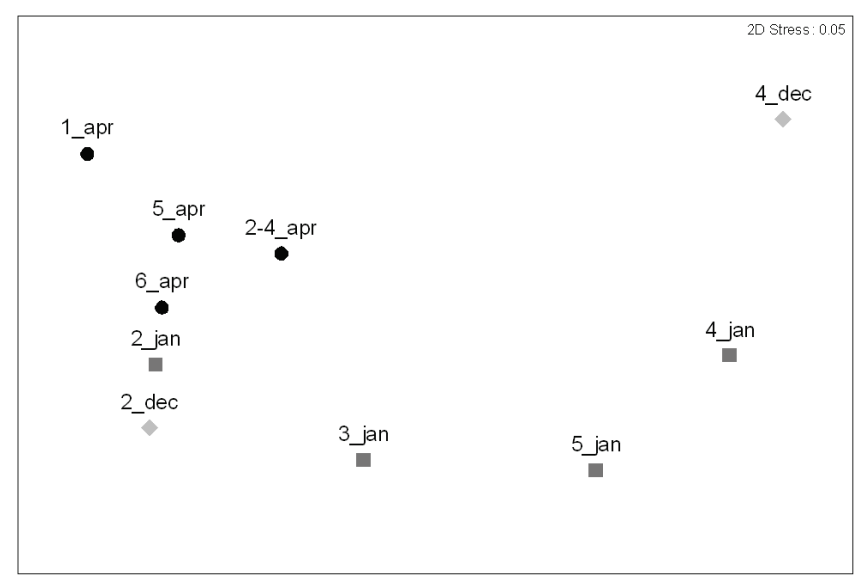

Fig. 4. Multi-dimensional scaling ordination scatter plot of the sample ostracod assemblages based on Bray-Curtis similarities on categorized species densities as indicated in table 3 . Sample and pond codes as in figure 3 and table 1.

pond expansion after high precipitation in April. Species emergence and succession was variable among ponds. Eucypris virens was one of the first ostracod species present after inundation along with Cypria ophtalmica, Cypris bispinosa, Fabaeformiscandona sp. n. ex gr. fabaeformis, H. chevreuxi and P. psammophila. Cypridopsis vidua and S. aculeata were observed in January. Bradleycypris obliqua, I. gibba, $H$. incongruens and $P$. marchica were recorded in April only along with $C$. hartwigi. The most abundant (density) species in this study was Cypridopsis vidua. The most common species (present in all six ponds) were C. bispinosa and Herpetocypris chevreuxi. Heterocypris incongruens, Ilyocypris gibba and Pseudocandona marchica were recorded in one sample only each.

The first two axes extracted by PCA accounted for a cumulative percentage of $93.7 \%$ of explained environmental variance. The occurrence of only eleven samples restricted any further ordination methods. The first axis (PCA 1: $64.6 \%$ ) is mainly correlated to $\mathrm{pH}$ and salinity while PCA $2(29.2 \%)$ is negatively correlated to dissolved $\mathrm{O}_{2}$ (Fig. 3). The samples with positive scores in the first axis are samples collected from the most acidic waters and with highest salinity. Samples collected from pond Font 4 in December and January and Font 1, Font 5 and Font 6 in April, with positive scores regarding axis 2 , are the samples with the lowest oxygen and highest temperature.

The ordination of the samples by the MDS technique based on faunistic similarity (Fig. 4) exhibited high similarity with that of the PCA ordination on the basis of abiotic factors (Fig. 3). Samples taken in December and January from Font 4 and in January from Font 5 , when the lowest $\mathrm{pH}$ and highest salinity was recorded, were dominated mainly by $C$. ophtalmica (Tab. 3). On the other hand, the cluster of the remaining samples (Fig. 4), with negative scores in the first PCA axis (Fig. 3), were samples mostly dominated by $H$. chevreuxi, $P$. psammophila and/or $C$. bispinosa (Tab. 3). 


\subsection{Regional survey}

From the survey carried out in Alentejo region, 10 ostracod species were recorded (three identifications questionable, see point 4.1.) belonging to four families (Tab. 2). Of these, two species were new records for mainland Portugal (Tonnacypris lutaria and P. psammophila) while Heterocypris sp., Ilyocypris aff. lacustris and T. lutaria were not recorded in the natural park PNSACV.

Species richness was on average 3.3 per pond (range: 2-5). The most common species was Eucypris virens followed by $H$. incongruens (occurring in nine and seven ponds, respectively). The least frequent species was $P$. psammophila, present in one pond only.

\section{DISCUSSION}

\subsection{Species richness: new records and taxonomic remarks}

Specimens assigned to the genus Candona (Appendix A1, figure a) may belong to C. neglecta, however the only male found among collected juveniles and females was damaged, not allowing an unambiguous identification to the species level. Regarding Heterocypris sp. (Appendix A2, figure f), the specimens retrieved were $<1.1 \mathrm{~mm}$ in length, belonging to the exigua class size of the genus (Petkovski et al. 2000). Specimens resemble H. exigua Gauthier \& Brehm (1928) the typical representative of this class. However, as the material consists only of females and juveniles (no males found), their specific assignment is ambiguous, and the record was left in open nomenclature as Heterocypris sp. Both Candona sp. ex gr. neglecta and Heterocypris sp. were not included in the annotated distributional checklist of Recent and Quaternary freshwater inland Ostracoda known from Portuguese mainland (Tab. 4).

Fabaeformiscandona sp. n. ex gr. fabaeformis (Appendix A1, figures $b, c)$ most probably represents a yet non described species. Our specimens resemble those of $F$. fabaeformis (Fischer 1851) with differences mainly in the shape of the female genital organ and of the Mprocess of the hemipenis, which is distally distinctively bifurcated. The latter character is shared with Eucandona svetozari (Petkovski \& Karanovic 2004) from specimens collected in Macedonia and with those from Spain originally assigned by Mezquita \& Sanz-Brau (1997) to F. fabaeformis. However, specimens collected in the present study differ from E. svetozari in valve shape. A detailed description of these specimens and a discussion on their taxonomic relationship will be published elsewhere. It is worth to mention that all former Portuguese records of $F$. fabaeformis, both recent and fossil, are given with some reserve (see Paulo \& Moutinho 1983; Cabral et al. 2005a; Minati et al. 2008). Therefore, these records may represent another species, while $F$. fabaeformis does not occur in Portugal or even in the whole Iberian Peninsula.

Until recently, only five species were known from the modern biotopes of the region Baixo Alentejo (Tab. 4; Paulo \& Moutinho 1983; Cearreta et al. 2003). In the region Alto Alentejo, on the other hand, there were no known published studies (Tab. 4). With the addition of the data from the present study a total of 18 recent freshwater ostracod species has now been recorded in the regions Alto and Baixo Alentejo. The present study also resulted in the discovery of six ostracod species new to recent continental Portuguese fauna (B. obliqua, C. bispinosa, I. aff. lacustris, P. psammophila, T. lutaria and the already mentioned $F$. sp. n. ex gr. fabaeformis) increasing a total number of the recent freshwater ostracod species recorded in mainland Portugal to 32 (Tab. 4).

The occurrence of B. obliqua, C. bispinosa, $P$. psammophila and T. lutaria in continental Portugal was not surprising given their presence in mainland Spain. However, if C. bispinosa (previously recorded in 1997 in Mata dos Medos, Costa da Caparica, ca $10 \mathrm{~km}$ from Lisbon; collection M.C. Cabral and R. Guerreiro, unpubl.) and T. lutaria are rather well known species, $P$. psammophila has only been sporadically reported in Europe. Although the species records in northern Europe derive mostly from lakes (Meisch 2000), its ecological preferences appear broader, as implied from its presence in temporary ponds (Smith \& Horne 2004; Martins et al. 2009) but also in a karstic lake (Mezquita et al. 1996) and in springs (Mezquita et al. 1999). The presence of bisexual populations of B. obliqua is of great interest given that male records for this species were reported from few sites in North Africa (Gauthier 1928; Klie 1943), one site in Croatia (Petkovski 1964) and one site in Central Spain (Roca et al. 2000) only. The species, despite the rather broad-based habitat incidence, has only few scattered records in Europe (though being known to occur in the archipelagos of Madeira and Azores) (Meisch 2000). A detailed description of the males of B. obliqua will be published elsewhere.

Along with the new records for continental Portugal, the finding of few other species is worth noting. The specimens of C. vidua (Appendix A3, figure a) recovered in the present sampling had brownish carapaces and as such may be assigned to C. parva Müller, 1900 which is considered by Meisch (2000) an intraspecific form of $C$. vidua. It is also worth noting the presence of C. vidua in Font 1 where oxygen level is very low. This may indicate that the species tolerance to low oxygenated waters may be wider than reported (see Meisch 2000). Ilyocypris lacustris is a rather rare European species with a few known published records in lakes only (Meisch 2000). Our specimens slightly differ in the carapace shape from those originally illustrated by Kaufmann (1900) and as such are denoted here with some reservation as I. aff. lacustris (Appendix A1, figure g). 
Tab. 4. Faunal checklist (in alphabetical order) of Recent (R) and fossil Quaternary (Holocene - H and Pleistocene - P) freshwater Ostracoda species recorded in mainland Portugal. References ordered in chronological order : 1. Petkovski 1963; 2. Petkovski 1964; 3. Paulo 1969; 4. Paulo \& Moutinho 1983; 5. Antunes et al. 1996; 6. Baltanás et al. 1996; 7. Gonzáles-Mozo et al. 1996; 8. Cearreta et al. 2003; 9. Cabral et al. 2004; 10. Cabral et al. 2005a; 11. Cabral et al. 2005b; 12. Hilbich et al. 2008; 13. Minatti et al. 2008. Species recorded in the present study are marked as NP (natural park) or/and RS (regional survey); species new to Portugal are in bold. $\hat{\sigma}$ - includes records of males in species reproducing primarily by parthenogenesis; ${ }^{\mathrm{a}}$ - as Candona cf. neglecta; ${ }^{\mathrm{b}}-\mathrm{dubious}$ identification; $^{\mathrm{c}}$ - refers to records originally ascribed by Petkovski (1963) to C. brincki (see synonymy in Petkovski et al. 1993); ${ }^{\mathrm{d}}-$ reported as Cypris cf. pubera; ${ }^{\mathrm{e}}$ - reported as Darwinula cf. stevensoni; ${ }^{\mathrm{f}}$ - reported as belonging to the genus Candona; ${ }^{\mathrm{g}}-$ reported as Fabaeformiscandona cf. fabaeformis; ${ }^{\mathrm{h}}$ - refers to records originally ascribed to bisexual populations of $H$. reptans (see discussion in Gonzáles-Mozo et al. 1996 and Meisch 2000); ${ }^{\mathrm{i}}$ - reported as belonging to the genus Erpetocypris; ${ }^{\mathrm{j}}$ - reported as Erpetocypris cf. reptans; ${ }^{\mathrm{k}}$ - reported as lyocypris gr. gibba $;{ }^{1}$ - reported as Eucypris cf. ornata; ${ }^{\mathrm{m}}$ - reported as belonging to the genus Cypridopsis; ${ }^{\mathrm{n}}$ includes records of $P$. villosa crassipes Masi, $1905 ;^{\circ}$ - reported as Candona parallela.

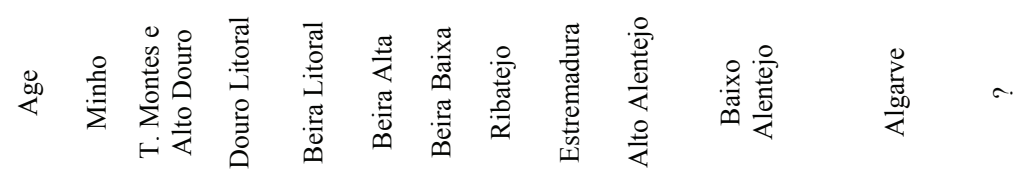

Bradleycypris obliqua (Brady, 1868)

Candona angulata Müller, 1900

Candona lindneri Petkovski, 1969

Candona neglecta Sars, 1887

Candona sanociensis Sywula, 1971

Cyclocypris laevis (Müller, 1776)

Cypria exsculpta (Fischer, 1855)

Cypria ophtalmica (Jurine, 1820)

Cypridopsis hartwigi Müller, 1900

Cypridopsis lusatica Schäfer, 1943

Cypridopsis vidua (Müller, 1776)

Cypris bispinosa Lucas, 1849

Cypris falki Janz, 1997

Cypris pubera (Müller, 1776)

Darwinula stevensoni (Brady \& Robertson, 1870)

Eucypris virens (Jurine, 1820)

Fabaeformiscandona fabaeformis (Fischer, 1851)

Fabaeformiscandona sp. n. ex gr. fabaeformis

Herpetocypris brevicaudata Kaufmann, 1900

Herpetocypris chevreuxi (Sars, 1896)

Herpetocypris intermedia Kaufmann, 1900

Herpetocypris mateusorum Paulo, 1969

Herpetocypris reptans (Baird, 1835)

Heterocypris incongruens (Ramdohr, 1808)

Heterocypris salina (Brady, 1868)

Ilyocypris bradyi Sars, 1890

Ilyocypris gibba (Ramdohr, 1808)

Ilyocypris aff. lacustris Kaufmann, 1900

Ilyodromus viridulus (Brady, 1886)

Koencypris cf. ornata (Müller, 1776)

Limnocythere inopinata (Baird, 1843)

Paralimnocythere compressa (Brady \& Norman, 1889)

Paralimnocythere messanai Martens, 1992

Paralimnocythere psammophila (Flössner, 1965)

Penthesilenula brasiliensis (Pinto \& Kotzian, 1961)

Plesiocypridopsis newtoni (Brady \& Robertson, 1870)

Potamocypris unicaudata Schäfer, 1943

Potamocypris villosa (Jurine, 1820)

Pseudocandona albicans (Brady, 1864)

Pseudocandona marchica (Hartwig, 1899)

Pseudocandona sp. ex gr. zschokkei (Wolf, 1920)

Sarscypridopsis aculeata (Costa, 1847)

Sclerocypris cf. bicornis (Müller, 1900)

Strandesia vavrai (G.W. Müller, 1898)

Tonnacypris lutaria (Koch, 1838)

Vestalenula cylindrica (Straub, 1952)

Vestalenula paglioli (Pinto \& Kotzian, 1961)

Zonocypris cf. costata (Vávra, 1837)

\begin{tabular}{|c|c|c|c|c|c|c|c|c|c|c|c|}
\hline $\mathrm{R}$ & & & & & & & & & $\mathrm{NP}^{\delta}$ & & \\
\hline $\mathrm{P}$ & & & & & & & & & & 10 & \\
\hline $\mathrm{R}$ & & & 4 & & & & & & & & \\
\hline $\mathrm{R}, \mathrm{P}$ & & & 4 & & & & & & $4, \mathrm{RS}^{\mathrm{a}}$ & $5^{\mathrm{a}}, 10,13$ & \\
\hline $\mathrm{H}$ & & & & & & & & & & 9 & \\
\hline $\mathrm{H}$ & & & & & & & & & & 9 & \\
\hline $\mathrm{R}$ & & & $4^{\mathrm{b}}$ & & & & & & & & \\
\hline $\mathrm{R}$ & 4 & & 4 & 4 & & 4 & & & NP & 4 & \\
\hline $\mathrm{R}$ & & & & & & 4 & & RS & NP,RS & & \\
\hline $\mathrm{R}$ & & & & & & & & & & & $1^{\mathrm{c}}$ \\
\hline $\mathrm{R}, \mathrm{H}, \mathrm{P}$ & & 4 & & 4 & & 4 & & & $4,8, \mathrm{NP}, \mathrm{RS}$ & 10 & \\
\hline $\mathrm{R}$ & & & & & & & & & $\mathrm{NP}$ & & \\
\hline $\mathrm{P}$ & & & & & & & & & & 10 & \\
\hline$P$ & & & & & & & & & & $5^{\mathrm{d}}$ & \\
\hline $\mathrm{R}, \mathrm{H}, \mathrm{P}$ & & & 4 & & & & & & $4,8^{\mathrm{e}}$ & $10,12,13$ & \\
\hline $\mathrm{R}$ & 4 & & & & & & & RS & NP,RS & & \\
\hline $\mathrm{R}, \mathrm{P}$ & & & $4^{\mathrm{b}, \mathrm{f}}$ & & & & & & & $10^{\mathrm{g}}, 13^{\mathrm{g}}$ & \\
\hline $\mathrm{R}$ & & & & & & & & & NP & & \\
\hline $\mathrm{R}$ & & & 4 & 7 & & & $4^{\mathrm{z} h}$ & & & & $2^{t}$ \\
\hline $\mathrm{R}$ & & & $4^{\mathrm{i}}, 7$ & & & $4^{\mathrm{i}}$ & $4^{i}$ & & NP & & \\
\hline $\mathrm{R}$ & & & & 7 & & & & & & & \\
\hline $\mathrm{R}$ & $4^{i}$ & & $3^{\mathrm{i}}, 4^{\mathrm{i}}$ & $4^{i}$ & 7 & $4^{\mathrm{i}}$ & $4^{i}$ & & & & \\
\hline $\mathrm{R}, \mathrm{P}$ & & & $4^{\mathrm{i}}$ & & & & 4 & & & $5^{\mathrm{j}}$ & \\
\hline $\mathrm{R}, \mathrm{P}$ & 4 & & 3,4 & & & 4 & 4 & RS & NP,RS & 10 & \\
\hline $\mathrm{R}$ & 4 & & 4 & & & & 4 & & & 4 & \\
\hline $\mathrm{H}, \mathrm{P}$ & & & & & & & & & 8 & 10,13 & \\
\hline $\mathrm{R}, \mathrm{H}, \mathrm{P}$ & & & & & & & & & $4,8, \mathrm{NP}, \mathrm{RS}$ & $4,5^{\mathrm{k}}, 10,13$ & \\
\hline $\mathrm{R}$ & & & & & & & & & RS & & \\
\hline $\mathrm{R}$ & & & & 6 & & & & & & & \\
\hline $\mathrm{H}$ & & & & & & & & & $8^{1}$ & & \\
\hline $\mathrm{H}, \mathrm{P}$ & & & & & & & & & 8 & 10 & \\
\hline $\mathrm{P}$ & & & & & & & & & & 10 & \\
\hline $\mathrm{P}$ & & & & & & & & & & 10 & \\
\hline $\mathrm{R}$ & & & & & & & & & NP,RS & & \\
\hline $\mathrm{P}$ & & & & & & & & & & 10,13 & \\
\hline $\mathrm{R}$ & $4^{1}$ & & $4^{3 \mathrm{~m}}$ & & $4^{\mathrm{m}}$ & $4^{\mathrm{m}}$ & $4^{\mathrm{m}}$ & & $4^{\mathrm{m}}$ & $4^{\mathrm{m}}$ & \\
\hline $\mathrm{R}$ & & & & & 4 & & & & & & \\
\hline $\mathrm{R}$ & & & $3,4^{\mathrm{n}}$ & & 4 & & 4 & & & & \\
\hline $\mathrm{R}$ & & & 40 & & & & & & & & \\
\hline $\mathrm{R}$ & & & $4^{\mathrm{f}}$ & & & & & & NP & & \\
\hline $\mathrm{P}$ & & & & & & & & & & 10 & \\
\hline $\mathrm{R}$ & & & & $4^{\mathrm{m}}$ & & & & & NP & 4 & \\
\hline $\mathrm{P}$ & & & & & & & & & & 10,11 & \\
\hline $\mathrm{R}$ & & & 4 & 4 & & & & & & & \\
\hline $\mathrm{R}$ & & & & & & & & RS & & & \\
\hline $\mathrm{P}$ & & & & & & & & & & 10,13 & \\
\hline $\mathrm{P}$ & & & & & & & & & & 10,13 & \\
\hline $\mathrm{P}$ & & & & & & & & & & $9,10,11$ & \\
\hline
\end{tabular}




\subsection{Environmental factors affecting ostracod distribution in the natural park PNSACV}

Freshwater ostracod species are composed of generalist species (cosmopolitans with wide environmental tolerances), specialist species with (in general) limited geographical distributions, and species which fall in between both extremes (Meisch 2000; Külköylüoğlu 2004). Consequently, studies of seasonal freshwater ostracod assemblages and their ecological predictors have since long been under study. The multivariate analysis (PCA) applied to summarise the most important environmental gradients in the studied sites within PNSACV showed that over $60 \%$ of the environmental variation was explained by the axis 1 and that this axis was highly correlated to $\mathrm{pH}$ and salinity (Fig. 3). Salinity and temperature have been suggested as primary factors constraining ostracod ecology and distribution (Neale 1964). The influence of $\mathrm{pH}$ on ostracod species distribution is related with problems in carapace calcification during the post-embryonic development, when calcium uptake in acid waters is difficult (Griffiths \& Holmes 2000). It has been recognized that at a $\mathrm{pH}<5$ ostracod species are in general absent (Boomer et al. 2006). Although in the samples collected in PNSACV salinity was within freshwater limits, with relatively low variation, $\mathrm{pH}$ was slightly acidic to neutral. These factors together with temperature (highly correlated with salinity and $\mathrm{pH}$ ), dissolved oxygen and organic matter content (among others) may have constrained the ostracod species presence and temporal succession. This containment is patent in the MDS analysis, confirming the main separation observed in the PCA: Samples with highest salinity and the lowest $\mathrm{pH}$ are characterised by the dominance of the eurytopic species $C$. ophtalmica. The general commonness and dominance of widely tolerant species (e.g., C. vidua, E. virens, H. incongruens) in addition to $\mathrm{pH}$ euryplastic species further support this idea.

Temporary water bodies usually have a large surface area to volume ratio, and for this reason they show hydrological characteristics very susceptible to weather fluctuation (Brönmark \& Hansson 1998). In Mediterranean temporary habitats hydrological conditions may function as a primer conductor in species distribution (Quintana et al. 1998). Therefore, despite the small area studied, species distribution in time and space varied among ponds as a probable effect of pond hydroperiod differences. Hydroperiod also influences habitat longevity and consequently community structure and complexity. Studies on temporary ponds suggest that species richness typically increases as the length of the flooded period in ponds increases (e.g., Neckles et al. 1990; Eyre et al. 1992). In this way, the observation that species richness per pond increased over the season was expected in the present study, as a combination of the presence of pure ephemeral inhabitants (e.g., H. incongruens) to species typical of more "mature" habitats (e.g., H. chevreuxi) and of the succession of early form species (e.g., E. virens) to summer forms (e.g., I. gibba). As a consequence, it is also understandable the observed seasonal increase in total ostracod density. This seasonal trend of increase was in great part caused by the emergence and population growth of $C$. vidua in April.

The nature of the "species reservoir" present in the sediment as diapausing eggs (egg bank) should also be considered when analysing the habitat characteristics. The study area was affected by severe droughts in 2004 and 2005 , with precipitation records at about $40 \%$ of the expected average annual precipitation for this region. In fact 2005 was the driest year recorded in continental Portugal since 1931, with the extreme drought recovering to a normal situation in March 2006 (www.meteo.pt). Yet, the presence of C. vidua, I. gibba, P. psammophila and Pseudocandona marchica which may be present in temporary water bodies but prefer permanent habitats (Meisch 2000) indicates that the study area may have a temporal to semi-permanent character. The presence of deep muddy sediment layers in the central zone of study area (the large depression inclosing ponds Font 2, 3 and 4), may permit water retention for long periods of time in this sector. Last, although salinity variation was reduced during the sampling period here studied, it is expected that highly variable water chemical conditions may occur, depending on annual hydroperiod conditions. The incidence of $C$. bispinosa, H. chevreuxi and Sarscypridopsis aculeata, with preference for brackish waters although inhabiting also pure freshwaters (Meisch 2000), may indicate such conditions. Moreover, the co-occurrence of $H$. chevreuxi and S. aculeata, as observed in January and April during this study, may be perceived as an indication of increasing salinity (Meisch 2000) which may have been restricted by high precipitation in early April. Considering the close distance to the sea, potential influence of sea water by sea spray or through the aquifer system should also be considered.

\subsection{Species richness: natural park PNSACV vs regional survey}

The surveyed ponds outside the natural park were ephemeral, rainwater fed, subjected to highly fluctuating conditions and located in rather altered human areas (road side ditches or agriculture grounds). Unlike the study area, which as a product of its unique geology may hold water/humidity for rather longer periods of time, the nine ponds in the regional survey are subjected to annual drying events, being more sensitive to annual hydrological conditions. Consequently as a combination of higher human activity and environmental unpredictability, the presence of lower ostracod richness was expected in the regional surveyed ponds $(10$ species comparing to 14 in the natural park PNSACV, with 6 species in common). Moreover, the presence of rather typical inhabitants of ephemeral waters and, in particu- 
lar, cosmopolitan species such as E. virens and $H$. incongruens was expected.

The unique settings of the study area in the natural park PNSACV define these habitats as exceptional, allowing the coexistence of both cosmopolitan and less tolerant species, and temporary to permanent water bodies' inhabitants. It should be noted though that one of the ponds with highest ostracod richness was Font 1 which exhibits the most short-lived characteristics. Font 1 is mostly dominated by sandy substrate of reduced water retention, with maximum depth below $0.5 \mathrm{~m}$. Therefore, despite the importance of the semi-permanent nature of the study site, other factors may contribute to the local ostracod richness of the study site.

\subsection{Known fossil Quaternary freshwater ostracod fauna in Portugal}

Most of the knowledge on the non-marine ostracod fauna from the Quaternary in continental Portugal derives from an outcrop assigned to the ?Pleistocene, located at Boliqueime, Algarve region (Cabral et al. 2005a). The corresponding deposits are interpreted as reflecting a fluvial- or alluvial-palustrine setting, with shallow, permanent waters of variable energy, developed under a warm climate, seasonally contrasting as regards to humidity. Up to now nineteen species have been recorded from this outcrop, from which five are common to the fauna studied in the Natural Park PNSACV and regional survey (Tab. 4): C. vidua, $H$. incongruens, I. gibba, C. neglecta and $F$. cf. fabaeformis. All of these species are tolerant to several environmental factors, usually inhabiting small ponds of permanent or temporary waters, having a wide distribution in Europe.

The presence of one species, Paralimnocythere compressa (Brady \& Norman, 1999), though unrepresented in the Recent fauna, must also be mentioned. $P$. compressa is morphologically very similar to $P$. psammophila, with the characteristics of the valves from both species almost impossible to distinguish. It is possible that the fossil population, mainly composed of juveniles (most difficult to identify), actually belongs to $P$. psammophila, widening the record of this species in Portugal to the Pleistocene.

\section{CONCLUSIONS}

In our study area, ostracod species distribution seems to have been conditioned by environmental settings with $\mathrm{pH}$ but also salinity as main variables and dissolved oxygen as a secondary determinant. The potential of mainland Portugal and of non-permanent water bodies as important reservoirs of ostracod fauna richness was patent, despite the small size of the studied area. Still, other characteristics of the study area, not only pond hydroperiod, should be considered when explaining the relative high ostracod richness encountered.
Temporary habitats may hold significant biodiversity serving as repositories of a diverse and valuable genetic heritage. These environments may provide habitat for rare and endangered species (Collinson et al. 1995 and references therein). The loss of Mediterranean temporary ponds as a result of human activities will conduct to the loss of unique ecological sanctuaries and vast biodiversity within the Iberian Peninsula, much of which remain poorly known (or even unreported). To an extent, the lack of correct management of temporary ponds reflects the lack of information about their ecology (Collinson et al. 1995).

\section{ACKNOWLEDGMENTS}

The help of Ana Pedro (Univ Évora), Lucyna Namiotko (Univ Gdańsk) and João Martins in sample collection is very much appreciated. Agnieszka Dobrzyńska, Anna Narloch and Anita Rudzka (Univ Gdańsk) assisted in the laboratory work. Telmo Nunes is acknowledged for assistance in the SEM pictures and Elisabete Nunes for the elaboration of the study area maps (Univ Lisbon). We also thank Claude Meisch (Mus. Nat. Hist. Nat. Luxembourg) for helpful comments on taxonomy and distribution of some of the recorded species and Francesc Mezquita (Univ València) for comments on the final version of the manuscript. This work was partially funded by the EU Marie Curie Research Training Network SexAsex (From Sex to Asex: a case study on interactions between sexual and asexual reproduction, contract MRTN-CT- 2004512492) and by the project MicroDyn (Microecology and Littoral Dynamics: definition of multi-proxies applicable to Quaternary palaeogeographical and palaeoclimatic reconstruction - POCTI/CTA/45185/2002), FCT, Portugal.

\section{REFERENCES}

Antunes, M.T., P. Mein, A. Nascimento \& J. Pais. 1986. Le gisement pleistocène de Morgadinho, en Algarve. Ciências da Terra, 8: 9-22.

Baltanás, A., B. Beroiz \& A. López. 1996. Lista faunística y bibliográfica de los ostracódos no-marinos (Crustacea, Ostracoda) de la Península Ibérica, Islas Baleares e Islas Canarias. In: J. García-Avilés \& E. Rico (Eds), Listas de la flora y fauna de las aguas continentales de la Península Ibérica. Associación Española de Limnología, Madrid 12: $1-71$.

Boomer, I., D.J. Horne \& R.J. Smith. 2006. Freshwater Ostracoda (Crustacea) from the Assynt region, NW Scotland: new Scottish records and a checklist of Scottish freshwater species. Bull. Inst. Roy. Sci. Belgique, Biologie, 76: 111123.

Brönmark, C. \& L.A. Hansson. 1998. The biology of lakes and ponds. Oxford University Press, New York: 216 pp.

Butlin, R.K., I. Schön \& H.I. Griffiths. 1998. Introduction to reproductive modes. In: K. Martens (Ed.), Sex and parthenogenesis. Evolutionary ecology of reproductive modes in non-marine ostracods. Backhuys Publishers, Leiden: 1-24.

Cabral, M.C., J.-P. Colin, \& P. Carbonel. 2004. First occurrence of the genus Zonocypris (Ostracoda) in the ?Pleistocene of Western Europe (Portugal). J. micropal., 23: 105106. 
Cabral, M.C., J.-P.Colin \& P. Carbonel. 2005a. Espèces pléistocènes de la famille Darwinulidae Brady et Norman, 1889 (Ostracodes), en Algarve, sud Portugal. Rev. Micropal., 48 : 51-62.

Cabral, M.C., J.-P.Colin \& P. Carbonel. 2005b. First occurrence of the genus Sclerocypris Sars, 1924 (Ostracoda) in the ?Pleistocene of Western Europe (Portugal). J. micropal., 24: 169-170.

Cabral, M.C., M.C. Freitas, C. Andrade \& A. Cruces. 2006. Coastal evolution and Holocene ostracods in Melides lagoon (SW Portugal). Marine Micropal., 60: 181-204.

Carbonel, P., J -P. Colin, D.L. Danielopol., H. Löffler \& I. Neustrueva. 1988. Paleoecology of limnic ostracodes: a review of some major topics. Paleogeogr. Paleoclimatol. Palaeoecol., 62: 413-461.

Cearreta, A., M. Cachão, M.C. Cabral, R. Bao \& M.J. Ramalho. 2003. Lateglacial and Holocene environmental changes in Portuguese coastal lagoons: 2. Microfossil multiproxy reconstruction of the Santo André coastal area. Holocene, 13: 447-458.

Chaplin, J.A., J.E. Havel \& P.D.N. Hebert. 1994. Sex and ostracods. Trends Ecol. Evol., 9: 435-439.

Clarke, K.R. \& R.N. Gorley. 2006. PRIMER v6: User manual/tutorial. PRIMER-E, Plymouth: $190 \mathrm{pp}$.

Cohen, A.C. \& J.G. Morin. 1990. Patterns of reproduction in ostracodes: A review. J. Crust. Biol., 10: 184-211.

Collinson, N.H., J. Biggs, A. Corfield, M.J. Hodson, D. Walker, M. Witfield \& P.J. Williams. 1995. Temporary and permanent ponds: an assessment of the effects of drying out on the conservation value of aquatic macroinvertebrate communities. Biol. Conserv., 74: 125-133.

Eyre, M.D., R. Cart, R.P. McBlane \& G.N. Foster. 1992. The effects of varying site-water duration on the distribution of water beetle assemblages, adults and larvae (Coleoptera: Haliplidae, Dytiscidae, Hydrophilidae). Arch. Hydrobiol., 124: 281-91.

Gauthier, H. 1928. Reserches sur la faune des eaux continentales de l'Argérie et de la Tunisie. Thésis présentées à la Faculté des Sciences de l'Université de Paris. ser. A. 1160: $1-423$.

Giere, O. 2009. Meiobenthology. The microscopic motile fauna of aquatic sediments. Springer-Verlag, Berlin Heidelberg: $527 \mathrm{pp}$.

González-Mozo, M.E., K. Martens \& A. Baltanás. 1996. A taxonomic revision of European Herpetocypris Brady and Norman, 1889 (Crustacea, Ostracoda). Bull. Inst. R. Sci. Nat. Belg., Biologie, 66: 93-132.

Griffiths, H.I. \& J.A. Holmes. 2000. Non-marine ostracods and Quaternary palaeoenvironments. Quaternary Research Association, Technical Guide 8, London: 188 pp.

Hilbich, C., I. Mügler, G. Daut, P. Frenzel, K. van der Borg \& R. Mäusbacher. 2008. Reconstruction of the depositional history of the former coastal lagoon of Vilamoura (Algarve, Portugal): A sedimentological, microfaunal and geophysical approach. J. Coastal Res., 24: 83-91.

Hindson, R.A. \& C. Andrade. 1999. Sedimentation and hydrodynamic processes associated with the tsunami generated by the 1755 Lisbon earthquake. Quat. Internat., 56: 27-38.

Hindson, R.A., C. Andrade, \& R. Parish. 1999. A microfaunal and sedimentary record of environmental change within the late Holocene sediments of Boca do Rio (Algarve, Portugal). Geol. Mijnbouw, 77: 311-321.

Holmes, J.A. \& A.R Chivas (Eds). 2002. The Ostracoda. Applications in Quaternary research. American Geophysical Union, Geophys. Monogr. 131, Washington DC: 313 pp.

Horne, D.J. 2004. Fauna Europaea: Ostracoda. In: G. Boxshall (Ed.), Fauna Europaea: Crustacea. Fauna Europaea version 1.1, http://www.faunaeur.org.

Kaufmann, A. 1900. Cypriden und Darwinuliden der Schweiz. Rev. Suisse Zool., 8: 209-423.
Klie, W. 1943. Ostracoden aus Marokko und Mauretanein. Zool. Anz., 143: 49-62.

Külköylüoğlu, O. 2004. On the usage of ostracods (Crustacea) as bioindicator species in different aquatic habitats in the Bolu region, Turkey. Ecol. Ind., 4: 139-147.

Lepš, I. \& P. Šmilauer. 2003. Multivariate analysis of ecological data using CANOCO. Faculty of Biological Sciences, University of South Bohemia, České Budějovice: 310 pp.

Loureiro, I.M., M.C. Cabral \& F. Fatela. 2009. Marine influence in ostracod assemblages of the Mira River estuary: Comparison between lower and mid estuary tidal marsh transects. J. Coastal Res., Special issue, 56: 1365-1369.

Martens, K., I. Schön, C. Meisch \& D.J. Horne. 2008. Global diversity of ostracods (Ostracoda, Crustacea) in freshwater. Hydrobiologia, 595: 185-193.

Martins, M.J.F., J. Vandekerkhove, F. Mezquita, O. Schmit, J. Rueda, G. Rossetti \& T. Namiotko. 2009. Dynamics of sexual and parthenogenetic populations of Eucypris virens (Crustacea: Ostracoda) in three temporary ponds. Hydrobiologia, 636: 219-232.

Meisch, C. 2000. Freshwater Ostracoda of western and central Europe. Spektrum Akademischer Verlag, Heidelberg, Berlin: $522 \mathrm{pp}$.

Mezquita, F. \& A. Sanz-Brau, A. 1997. New records of the genus Fabaeformiscandona (Fischer, 1851) in the Iberian Peninsula. Crustaceana, 70: 504-507.

Mezquita, F., A. Sanz-Brau \& M.R. Miracle. 1996. New data on freshwater assemblages (Crustacea, Ostracoda) from Cuenca (Central Spain). Bulletin de la Société des Naturalistes Luxembourgeois, 97: 239-247.

Mezquita, F., G. Tapia \& J.R. Roca. 1999. Ostracoda from springs on the eastern Iberian Peninsula: ecology, biogeography and palaeolimnological implications. Paleogeogr. Paleoclimatol. Palaeoecol., 148: 65-85.

Minati K., M.C. Cabral, R. Pipik, D.L. Danielopol, J. Linhart \& W. Neubauer. 2008. Morphological variability among European populations of Vestalenula cylindrica (Straub) (Crustacea, Ostracoda). Palaeogeogr. Palaeoclimatol. Palaeoecol., 264: 296-305.

Moore R.C. (Ed.). 1961. Treatise on invertebrate Paleontology. Part Q. Arthropoda 3, Crustacea, Ostracoda. Geol. Soc. Am. Univ. Kansas Press, Kansas: 442 pp.

Neale, J.W. 1964. Some factors influencing the distribution of recent British Ostracoda. Pubbl. Staz. Zool. Napoli, 33: 247-307.

Neckles, H.A., H.R. Murkin \& J.A. Cooper.1990. Influences of seasonal flooding on macroinvertebrate abundance in wetland habitats. Freshwat. Biol., 23: 311-322.

Oertli, H.J. 1982. Early research on Ostracoda and the French contribution. In: R.H. Bate, E. Robinson \& L.M. Sheppard (Eds), Fossil and recent ostracods. Ellis Horwood Limited, Chichester: 454-478.

Oliveira, J. T. (Coord.) 1984. Carta Geológica de Portugal, 1:200 000, Folha 7, Serviços Geológicos de Portugal.

Oliveira, J.T., Pereira, E., Ramalho, M., Antunes, M.T \& Monteiro, J.H. (Coords). 1992. Carta Geológica de Portugal, 1:500,000, Serviços Geológicos de Portugal.

Paulo, L.F. 1969. Contribution à l'étude des ostracodes du Portugal (Note sur une nouvelle espèce du genre Herpetocypris). Publ. Inst. Zool. Dr. A. Nobre, 108: 1-13.

Paulo, L.F. \& M. Moutinho. 1983. Systématique et distribution des ostracodes au Portugal. Publ. Inst. Zool. Dr. A. Nobre. Fac. Sci. Porto, 173: 1-32.

Petkovski, T.K. 1963. Über Süsswasser-Ostracoden der Azoren. Bol. Mus. Munic. Funchal, 17 (62): 49-65.

Petkovski, T.K. 1964. Bemerkenswerte Entomostraken aus Jugoslavien. Acta Mus. Maced. Sci. Nat., 5 (11): 61-69.

Petkovski T.K. \& I. Karanovic. 2004. Eucandona svetozari sp. n., a freshwater ostracod from Macedonia (SE Europe) (Crustacea, Ostracoda, Candoninae). Senckenberg. biol., 83(2): 103-111. 
Petkovski T.K., C. Meisch \& K. Wouters. 1993. Taxonomic revision of the freshwater Ostracoda species Cypridopsis lusatica Schafer, 1943 (Crustacea). Trav. Sci. Mus. Hist. Nat. Luxemb., 19: 49-66.

Petkovski T., B. Scharf \& D. Keyser. 2000. New and little known ostracods of the genus Heterocypris (Crustacea, Ostracoda) from the Balkan Peninsula. Limnologica, 30: 45-57.

Quintana, X.D., F.A. Comín \& R. Moreno-Amich. 1998. Nutrient and plankton dynamics in a Mediterranean salt marsh dominated by incidents of flooding. Part 2. Response of the zooplankton community to disturbances. $J$. Plankton Res., 20: 2109-2127.

R Development Core Team. 2008. R: A language and environment for statistical computing. The $\mathrm{R}$ project for statistical Computing, www.r-project.org.
Ribeiro, O. \& H. Lautensach. 1988. Geografia de Portugal II. O ritmo climático e a paisagem. Edições João Sá da Costa, Lisboa: 337-623.

Roca J.R., F. Mezquita, J. Rueda, A. Camacho \& M.R. Miracle. 2000. Endorheic versus karstic lakes: patterns of ostracod distribution and lake typology in a Mediterranean landscape (Castilla - La Mancha, Spain). Mar. Freshwater Res., 51: 311-319.

Smith R.J. \& D.J. Horne. 2004. The first British record of Paralimnocythere psammophila (Flössner, 1965) (Ostracoda, Cytheroidea, Limnocytheridae). J. micropal., 23: 133-134.

ter Braak, C.J.F. \& P. Šmilauer. 2002. CANOCO reference manual and CanoDraw for Windows user's guide: Software for canonical community ordination (version 4.5). Microcomputer Power, Ithaca, NY: 500 pp.

\section{A P P E N D I X}

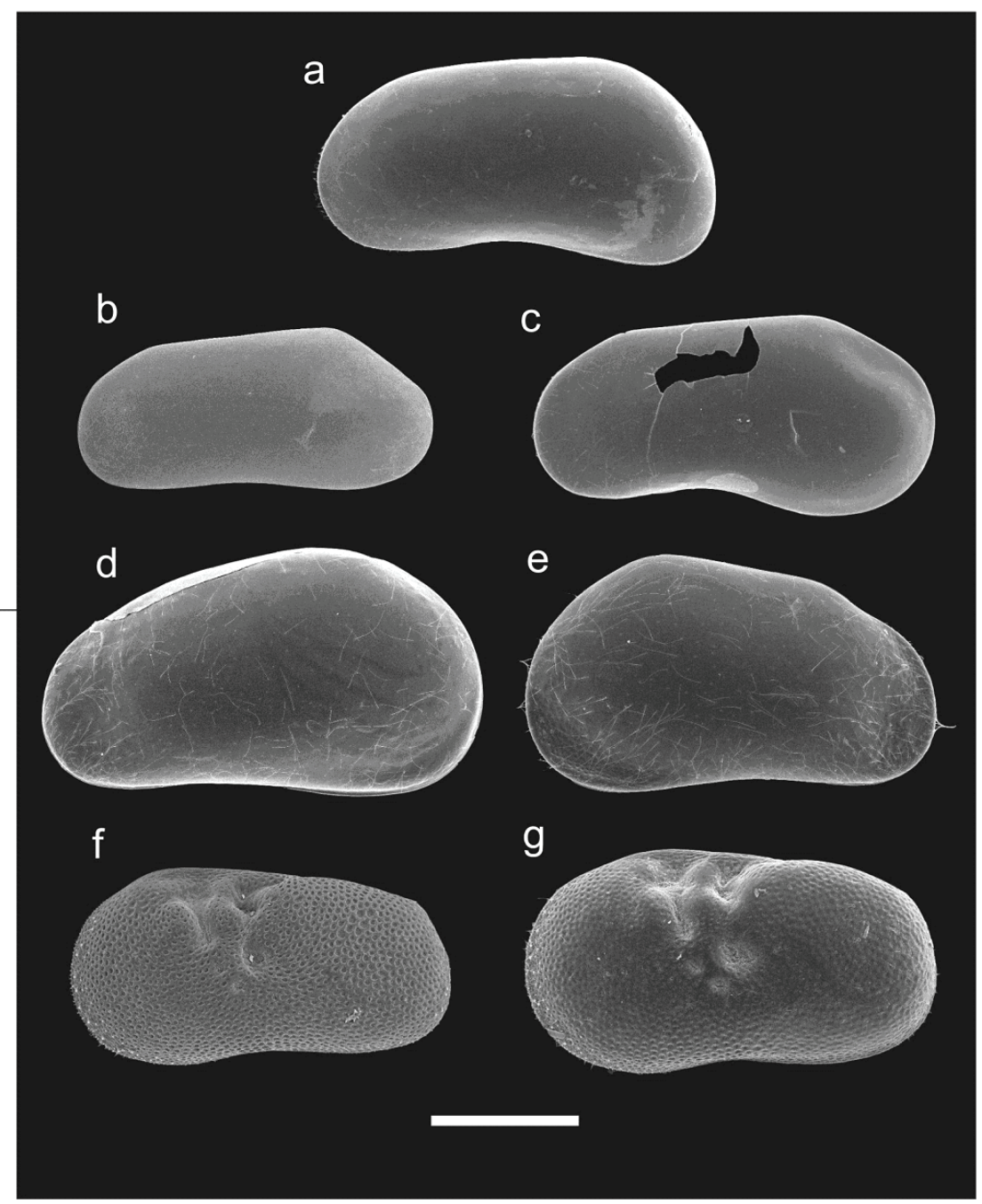

Plate A1. SEM pictures of the ostracod species recorded in the region Alentejo. a. Candona sp. ex gr. neglecta: female, lateral view, left valve (scale bar = $382 \mu \mathrm{m}$; sample: SXPO020); b, c. Fabaeformiscandona $\mathrm{sp}$. n. ex gr. fabaeformis: b. subadult female, lateral view, left valve (scale bar $=287 \mu \mathrm{m}$; sample: Font 2-4 Apr), c. male, lateral view, left valve (scale bar = 382 $\mu \mathrm{m}$; sample: Font 2-4 Apr); d, e. Pseudocandona marchica: d. male, lateral view, left valve (scale bar $=383 \mu \mathrm{m}$; sample: Font 1 Apr), e. female, lateral view, right valve (scale bar $=378 \mu \mathrm{m}$; sample: Font 1 Apr); f. Ilyocypris gibba: female, lateral view, left valve $(\mathrm{scale}$ bar $=385 \mu \mathrm{m}$; sample: Torp2); g. Ilyocypris aff. lacustris: female, lateral view, left valve (scale bar $=389 \mu \mathrm{m}$; sample: SXPO019). 


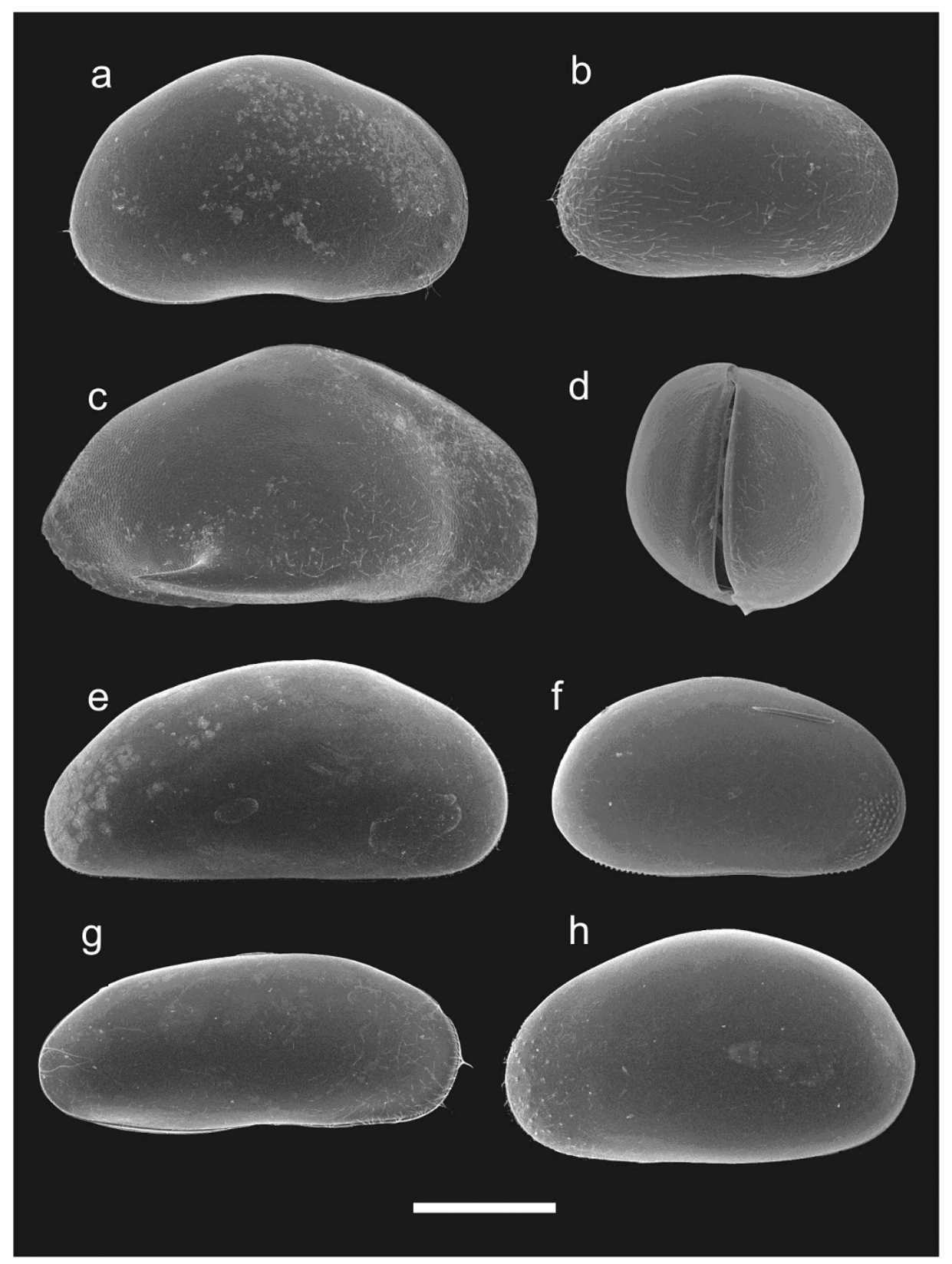

Plate A2. SEM pictures of the ostracod species recorded in the region Alentejo (continued). a. Eucypris virens: female, lateral view, right valve (scale bar $=778 \mu \mathrm{m}$; sample: Font 2 Jan); b, d. Bradleycypris obliqua: b. female, lateral view, right valve, d. female, carapace frontal view (scale bar $=516 \mu \mathrm{m}$; sample: Font 2-4 Apr); c. Cypris bispinosa: female, lateral view, right valve (scale bar = $809 \mu \mathrm{m}$; sample: Font 2-4 Apr); e. Tonnacypris lutaria: female, lateral view, right valve (scale bar = 706 $\mu \mathrm{m}$; SXP0021); f. Heterocypris sp.: female, lateral view, right valve (scale bar $=376 \mu \mathrm{m}$; sample: SXPO020); g. Herpetocypris chevreuxi: female, lateral view, right valve (scale bar $=776 \mu \mathrm{m}$; sample: Font 2-4 Apr); h. Heterocypris incongruens: female, lateral view, left valve (scale bar $=517 \mu \mathrm{m}$; sample: Torp 2). 


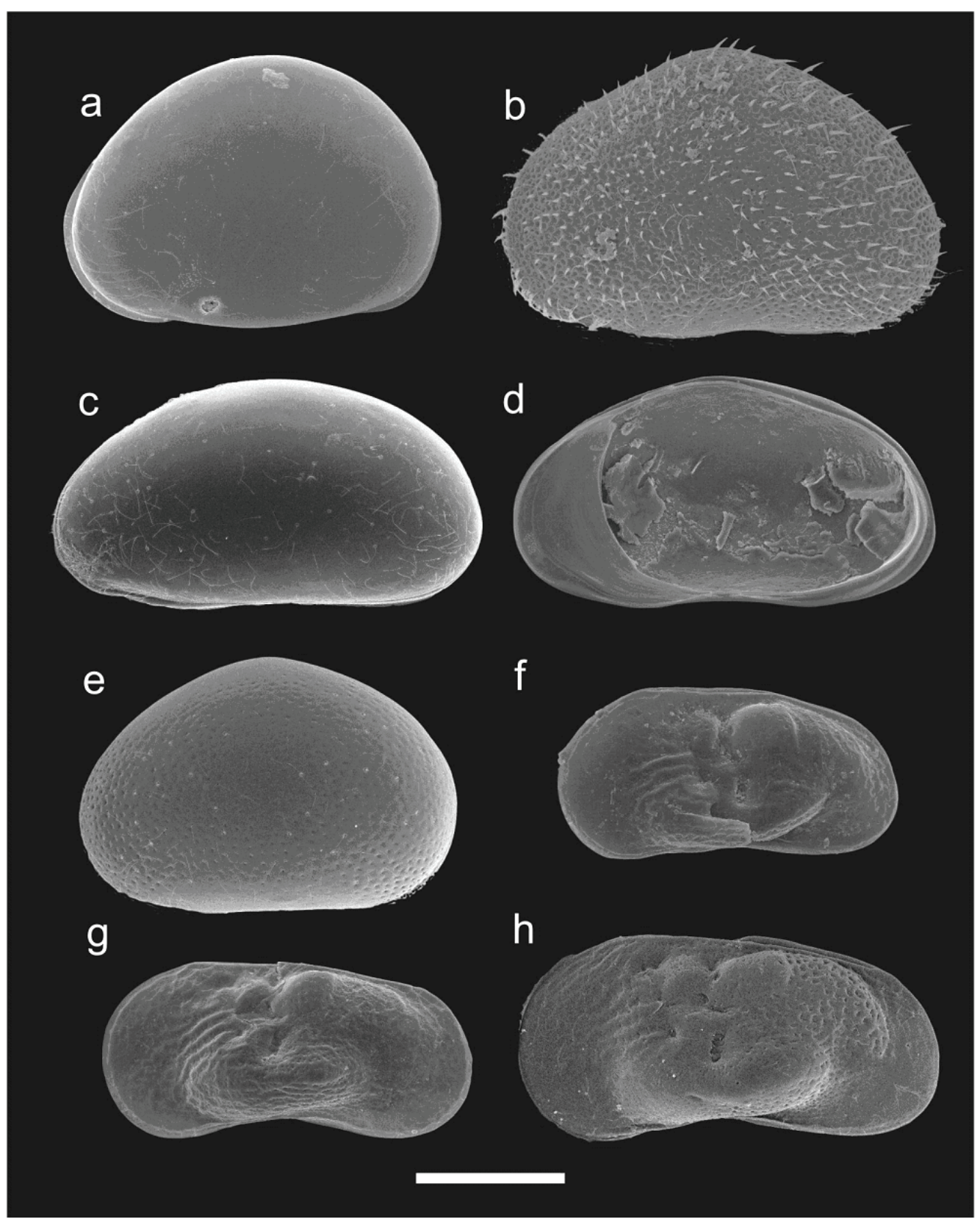

Plate A3. SEM pictures of the ostracod species recorded in the region Alentejo (continued). a. Cypria ophtalmica: female, lateral view, left valve (scale bar $=259 \mu \mathrm{m}$; sample: Font $3 \mathrm{Jan})$; b. Sarscypridopsis aculeata: female, lateral view, left valve $(\mathrm{scale}$ bar $=$ $259 \mu \mathrm{m}$; sample: Font 2 Jan); c-d. Cypridopsis hartwigi (scale bar $=252 \mu \mathrm{m}$; sample: Font 2-4 Apr): c. female, lateral view, left valve, d. female, internal view, right valve; e. Cypridopsis vidua: female, lateral view, left valve (scale bar $=196 \mu \mathrm{m}$; sample: Font $2-$ 4 Apr); f-h. Paralimnocythere psammophila: f. juvenile carapace, left side (scale bar $=208 \mu \mathrm{m}$; sample: Font 2 Dec), g. male carapace, left side (scale bar $=208 \mu \mathrm{m}$; sample: Font 2-4 Apr), h. female, lateral view, left valve (scale bar = 252 $\mu \mathrm{m}$; sample: Font 2 Jan). 